\section{Paradox of Human Capital Development and SDGs Implementation in Nigeria}

Chukwuemeka Emma ${ }^{1}$, Ngozi Ewuim ${ }^{1}$ and Ikechukwu Ogeze Ukeje ${ }^{2}$

${ }^{1}$ Department of Public Administration, Nnamdi

Azikiwe University, Awka, Nigeria

${ }^{2}$ Department of Political Science, Alex Ekwueme

Federal University, Ndufu-Alike, Abakaliki,

Ebonyi State, Nigeria

\section{Synonyms}

2030 United Nations (UN) Agenda; Human capital development; Policy implementation; Public policy; Sustainable development goals

\section{Definition}

\begin{tabular}{|c|c|}
\hline $\begin{array}{l}\text { Human capital } \\
\text { development }\end{array}$ & $\begin{array}{l}\text { The process of creating } \\
\text { opportunities in the aspect of } \\
\text { social and economic } \\
\text { empowerment through } \\
\text { training, workshops, } \\
\text { coaching, consultation, and } \\
\text { cultivating environments in } \\
\text { which human beings } \\
\text { (individuals) can rapidly } \\
\text { learn and apply new ideas, } \\
\text { competencies, skills, }\end{array}$ \\
\hline
\end{tabular}

behaviors, and attitudes for task actualization and sustainability.

\section{Sustainable Development Goals} The launch of United Nations (UN) Sustainable Development Goals (SDGs) with 17 Goals by world leaders on September 25,2015 , opened up both governmental and commercial nongovernmental actions on the approaches that will produce solution to the problems of poverty, food security, inequality and injustice, and tackle climate change by 2030 . This is contained in a document "Transforming our World: the 2030 Agenda for Sustainable Development." Each government will also decide how these aspirational and global targets should be incorporated into national planning processes, policies, and strategies. It is important to recognize the link between sustainable development and other relevant ongoing processes in the economic, social, and environmental 
fields (UN General Assembly 2015, p. 13).

Policy
Implementation

It involves a general political

and technical process of

enforcing government

intentions, decisions, and

programs to address societal

pressing demands or needs

(Ayisi et al. 2018).

\section{Introduction}

There is a desperate need for a sound human capital intervention (SHCI) policy reform in Nigeria if the country is to achieve the targets set in the 2030 Agenda. World over, HCD remains a central element in the development of any individual, nation, state, or institution. Thus, effective implementations of practical Human Capital Intervention Policies (HCIPs) and programs are the necessary foundations and platform for Sustainable Development Goals (SDGs) (Dialoke et al. 2017; Jooji and Oguchi 2017) and poverty reduction since poverty manifests through lack of basic needs (Dzanku 2019). Public policy implementation (PPI) involves "a general political and technical process of enforcing government intentions, decisions, and programs to address societal pressing demands or needs" (Ayisi et al. 2018). No doubt career bureaucrats are responsible for coordinating, monitoring, and enforcing implementation activities (Jooji and Oguchi 2017; Ukeje et al. 2020c) of public policies in the various ministries and or/agencies of the government; but they cannot deliver all the SDGs strategies effectively without involving local public stakeholders, acting in collaborative partnership to implement the goals.

Thus, the capabilities of government bureaucracy in terms of expertise, skill orientation, and experience determine to a large extent the success or failure of policy implementation (Osawe 2015; Ighodalo 2018), including human capital food security program (HCFSP). However, studies have shown that public policy reform and intervention in Nigeria have witnessed a declining performance in spite of several efforts geared toward transforming the system to reposition the country's bureaucracy for an improved citizens' welfare (Offu et al. 2018; Ukeje et al. 2019). The reality of Nigerian bureaucracy is dominant politicization and unavowed institutionalized corruption. There are extant rules and established bureaucratic procedures, but they simply exist in nominal plane: they can easily be breached with impunity by both politicians and top bureaucrats (Ukeje et al. 2019) due to lack of soundadministrative system and or governance in the country. Importantly, sound political process and effective institutions require committed political leadership, clear direction, and appropriate strategic influence and the very fact that none of these will happen without a robust governance structure (Momen and Begum 2020).

Developing human capitals (HCs) requires creating opportunities in the aspect of social and economic empowerment through training, workshops, coaching, consultation, and cultivating environments in which human beings (individuals) can rapidly learn and apply new ideas, competencies, skills, behaviors, and attitudes for task actualization and sustainability (Ozoya 2016). These have serious implications for the realization of good and sound governance objectives. Generally, the success or failure of any meaningful HCIPs is a function of its human capital, governance, strategies, and implementation and the impact it has on the citizens who are the Real Policy-Target Beneficiaries (RPTBs). However, current literature in the field of policy studies, governance, and development administration (Ayisi et al. 2018; Olavarria-Gambi 2018) have explored the dynamics in policy implementation processes and examined some reasons policies fail or succeed - or are claimed to have failed and link policy failure or the perception of failure (Grace et al. 2017) to variations in learning (Zhang 2017) whereby knowledge, policies, or administrative arrangements shift from one nation or policy domain to another, intent and outcome (O'Toole 2004) for a better understanding of the game in PPI and that certain policies fail (McConnell 2015; Ayisi et al. 2018) when the outcome deviates from the intention (Agyepong and Adjei 2007). Policy analysis and 
implementation is a multidisciplinary and systematic investigation aimed at gathering and analyzing information about likely consequences of public policies both before and after they occur (Ezeani 2006) and the activities that are carried out in light of established policies in order to ensure that programs are meeting their intent (Atkinson 2017).

Importantly, Howlett and Ramesh (2003) stressed the need for a comprehensive knowledge by policy drivers in a systematic and controlled manner for the attainment of policy goals and objectives (Parsons 1995). However, a policy is successful when implementation bears relationship to the intentions of policy adopters (Olavarria-Gambi 2018). This can only be achieved through citizen participation as an element of sound governance (Farazmand 2012, 2017) giving them the opportunity to take part in decision-making that addresses their concerns (Ricciardelli 2018). Sound governance also implies sound policy in administrative, managerial, and organizational processes that are participatory and engaging rather than elitist and corporatist in character (Farazmand 2017).

Sound governance-driven HCIPs often build on the people's expressed will, wider participation, and justice. Adopting a sustainable food system agenda requires multiple stakeholders for sustainability (Bene et al. 2019). Fischer-Smith (2018) contends that policy implementation loses its effectiveness when those charged with the responsibility of implementation act in the manner opposed to the policymakers' specified intentions, which often includes divergence between the policy design and implementation processes. This entry raises questions about the missing link in the formulation of human capital intervention (HCI) policy programs, design, implementation, outcome, and more importantly, sustainability especially in this era of SDGs that has challenged the capacity of public service and service delivery especially in developing nations.

It is noted that policy failure, success, and/or performance in Nigeria public sector organizations is predicated on the ideology of the policydrivers due to the forces of state-elite capture, corruption, and politicization of the process of
HC acquisition. The paradox of HCD and SDGs implementation in the context of this entry interrogates the political manipulation and interest sharing saga of the state government using the cooperative-society organizations (CSOs) approach in disbursing the HCI and empowerment scheme and the choice of who gets the rare opportunity for HCD in the civil service of Ebonyi state in particular and Nigeria in general.

There is no prior study on the link between SDGs policy implementation, HCIPs, and poverty reduction within the framework of institutional capacity-capability approach applied to the Nigerian context. This has implications for the attainment of a result-oriented Human Capital Intervention Reforms (HCIRs) and SDGs policy targets and indicators in Nigeria democratic governance since previous HCIPs research has paid little attention to the relevance and development of institutional capacity building within the Ministry of Agriculture and Natural Resources (MoANRs) and whether the professional personnel's (agricultural experts) were part of the conception/formulation of the various HCIPs and empowerment scheme in the state.

Based on established HCIPs and poverty reduction concepts and relationships, a conceptual model linking HCIPs, poverty reduction, and sustainability indicators in Ebonyi state MoANRs is introduced. The remaining part of this entry is structured as follows. Firstly, a brief review of literature (research background) on the nature of public policy, governance, and ideological leanings of previous HCIPs and poverty reduction efforts of governments in developing countries and the challenges in Nigeria's HCD system is presented. Secondly, the research methods used in this study are discussed. The third section presents the link between HCD and SDGs 1 and 2 targets and indicators; and also, the implications for Nigeria's project management and development. The fourth section presents and analyses the findings of the study. The final section concludes with a discussion of the findings and a review of the implications for future research in managing HCIRs. 


\section{Conceptual and Analytical Framework}

\section{Linking HCIPs, Poverty Reduction and Sustainability Indicators in Ebonyi State MoANRs}

The conceptual model in Fig. 1 attempts to connect the different research questions in order to determine the dependent variable, FSP implementation (see below). The central research question is "To what extent are there clear strategies set for increasing the knowledge and skill of the policy drivers (bureaucrats) and the RPTBs for sustainable Agric policy implementation?" This analytical framework assumes that the human capital capability (HCC) of the policy drivers influences the quality of policy formulation and implementation of public policies. As well, the institutional capacity of the ministry influences the type of public policies that will be implemented by the government. These two intervening variables will also affect the initiation of HCIRs in the ministry. Generally, the HC condition and capabilities of the implementing agency and/or ministry (policy drivers) influence these variables collectively and individually, and this ultimately will affect the performance of Agric policy. The research model of the performance of the Ebonyi State Ministry of Agriculture and Natural Resources (EBSMoANRs) (see Fig. 1) depicts this.

The paradox of HCD and SDGs implementation in the context of this entry interrogates the political manipulation and interest sharing saga of the state government using the CSOs approach in disbursing the HCI and empowerment scheme and the choice of who gets the rare opportunity for HCD in the public service of Ebonyi state in particular and Nigeria in general. The practice of using cooperative-society organizations (CCOs) in disbursing the HCD interventions should be discontinued.

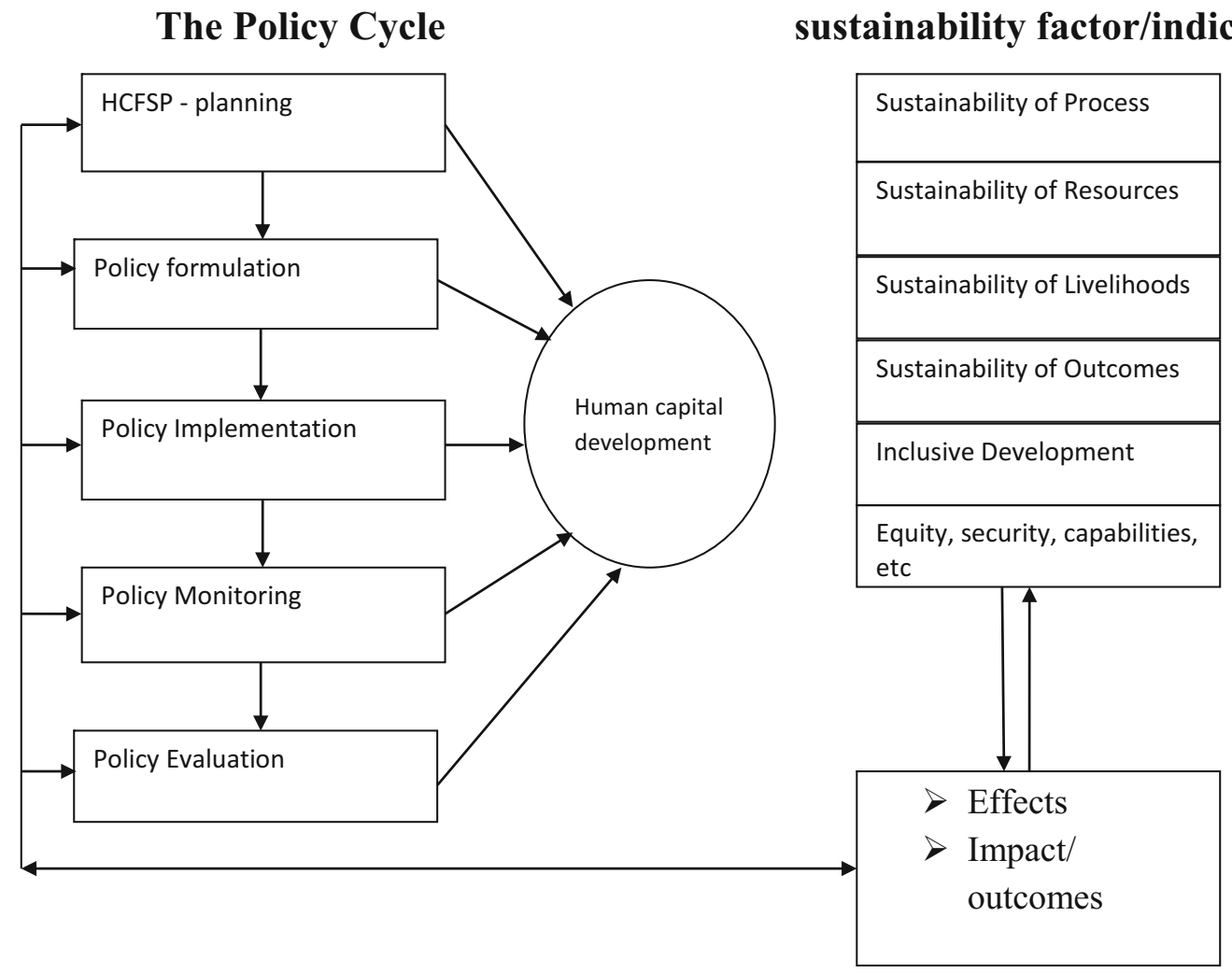

Paradox of Human Capital Development and SDGs Implementation in Nigeria, Fig. 1 Research model of institutional performance: Ebonyi State Ministry of Agriculture and Natural Resources. (Source: Ukeje 2020, p. 10) 
The use of local community-based poverty intervention mechanisms (LCBPIMs) is preferred as a better and result-oriented participatory governance/approach that encourages strong synergy between the citizens and the implementing ministry/agency. More so, empowering local-public stakeholders will enhance the quality and sustainability of public services.

\section{Research Background}

\section{Linking Sound Governance Approach to Human Capital Development and SDGs Implementation: Policy, Obstacles, and Performance}

In recent times, sound governance policy reforms remains one of the major machineries through which the society is placed at global perspective. According to Farazmand (2004, p. 81):

\begin{abstract}
Sound governance is presented as a more comprehensive notion of governance that encompasses the concept of good governance and sound public administration for all people. Governance is sound when it includes all people or their genuine representatives in the process of governance and administration without political or economic intimidation or domination by powerful elites operating on their own behalf or promoting the interests of global corporate elites of the Western governments.
\end{abstract}

The process of HCIRs and development must be so comprehensively conceived for the real food security policy (FSP) issues to be addressed (Ukeje et al. 2020b). Over the years and since the creation of Ebonyi state in 1996, the nature and practice of PPI for development by successive governments on tackling FSP and poverty reduction in Nigeria have severally been engrossed on provision of social services such as borehole, roads, credit schemes, agricultural extension services, tax and tariff administration, creation of empowerment, or endowment funds (credit scheme, conditional/non-conditional cash transfer (CCT), etc.) with little focus on tackling HCIRs from the capability-based approach through training and education of the policy drivers (bureaucrats) and the RPTBs in the various communities and villages of the state.
Though previous studies like Anger (2010), Anyanwu (2011), and Ojo and Adebayo (2012) have appraised the performance of various HCIPs for poverty reduction in Nigeria and other developing countries, they have not empirically investigated the capability of the policy-target beneficiaries (CPTBs) in the process of PPI in the remote communities of Abakaliki, Ebonyi State. The challenge is that the entire process of HCD through empowerment policy programs is riddled with politics while the RPTBs lack access, capacity, and training needed to succeed in the PPI process. Other research findings on governance effectiveness, institutional management, and policy reforms in Nigeria identified and implicated inadequate manpower development and poor HRs planning (Okpata and Ukeje 2011) as a major challenge to the provision of quality services, capacity building, and developmental services due to "external influences, nepotism and political cleavages" (Ndukwe et al. 2015) in the bureaucratic institution since bureaucracy without bureaucratization can provide an explanation for the underlying problems of inefficiency and ineffectiveness (Ukeje et al. 2019).

Presently, a UN development agenda has been initiated in the form of SDGs with about 17 goals, 169 targets, and 231 indicators (Ukeje et al. 2020c) as an extension of the expired Millennium Development Goals (MDGs) and aims to end poverty and improve the lives of the citizens in a sustainable and inclusive manner by 2030 (Jaiyesimi 2016; Ogu 2019). This study raises question on the preparedness/capabilities of Nigerian ministries, that is, the bureaucrats (human capitals) to drive the policy and achieve its results by 2030 since the immediate past 2015 MDGs of the United Nations (UN), in Nigeria did not achieve all the desired results as stated in the policy framework (Kauzya 2015; Ezirim et al. 2016; Thornton et al. 2018). Yet, human capital remains the key to unlocking national potential accompanied by greater productivity (Ndukwe et al. 2016; Ukeje et al. 2020a) and sustainability of the policy impact due to the nature of the actual economic and political environment (Ukeje et al. 2020c) in the country. 
This is because institutional policy outcome is a function of participatory engagements of the right human capitals, skill, and orientation in the policy-making process. Thus, basic factors influencing policy failures and/or success includes lack of involvement of the RPTBs, training and re-training of the project team, external politics in the PPI stage, nepotism, and political cleavages (Ndukwe et al. 2015) in the selection of RPTBs in the project community. Okechukwu et al. (2016) also identified the practice of "...who sent you syndrome; complimentary card paradox or deification madness," as the reasons for policy failures in public bureaucracy.

Sustainable HCFSP and poverty reduction are driven by the institutional capacity of the implementing agency or ministries to meet the citizens required level of food consumption through practical HCIRs in a sustained and systematic manner to end rural poverty and hunger. Addressing HCIRs only in economic sense without recourse to the education and capability aspect has characterized Nigeria's HCI and development policies (Ukeje et al. 2020a). This underlines the focus of SDGs 1 - which aims to end poverty in all its forms everywhere, and goal 2 - End hunger, achieve food security and improved nutrition, and promote sustainable agriculture (UN General Assembly 2015; see Tables 1 and 2).

However, although countless development efforts (policies) were made by different administration in the form of development plans from 1960 to date, Onah (2010) observed that Nigeria has gone through four national development plans (NDP), and has been engaged in the process and task of rolling out several development initiatives such as the Rolling Plans, Vision 2010-2020, the National Economic Empowerment and Development Strategy (NEEDS) in order to promote development, yet traces of poverty and hunger remain on the high side (Fatile and Ajulor 2018; Ukeje et al. 2020b). This is because the challenge of sustainable development and policy reforms in Nigeria public service is hinged on the practice of "bio-politics" and "geo-politics" determinants of who should be engaged following "kinship" (communal) and "geographical" political affiliations (Ukeje et al. 2020c).
Considering the above instances, it is worthy of note that institutional HCD remains the brain behind the attainment of 2030 global agenda in Ebonyi State. This entry therefore focuses on the effectiveness of HCIRs for effective implementation of SDGs (1 and 2) which aim to end poverty in all its forms everywhere and end hunger, achieve food security and improved nutrition, and promote sustainable agriculture by 2030 as a panacea for sustainable development in Ebonyi State, Nigeria.

Poverty reduction has been defined as strategic policy measures, both economic and humanitarian, that are intended to permanently lift people out of poverty (Ukeje et al. 2020a, p. 1) that is anchored on the three pillars of social, economic, and environmental preservation for the guaranteed present and future generations. HCD and poverty reduction should be guided by sound and friendly empowerment strategies that enhance self-reliance and self-esteem, through active participation of the right $\mathrm{HCs}$ in the stages of policy process. Thus, both theoretical and empirical researches have been undertaken on human capital development, governance, and PPI in Nigerian democratic government (Anger 2010; Metu et al. 2016; Dialoke et al. 2017) in recent times but studies have failed to address the capability of the human capitals and the needs of public sector institutions. A recent study on the practice of HCI and PPI in Nigeria revealed that in spite of laudable policy programs embarked upon by different governments, the genuine poor farmers with passion and significant years of experience were undeservedly excluded from the empowerment opportunities (Ukeje et al. 2020b) due to the nature of our politics and the institutional environment. This has made the attainment of policy goals difficult. This is because effective provision and delivery of essential public services through implementation of government's programs and policies is the core object of public bureaucracy (Ukeje et al. 2019). 
Paradox of Human Capital Development and SDGs Implementation in Nigeria, Table 1 Specific targets of SDG 1 - end poverty in all its forms everywhere

\begin{tabular}{l|l}
\hline 1.1 & $\begin{array}{l}\text { By 2030, eradicate extreme poverty for all people everywhere, currently measured as people living on less than } \\
\text { \$1.25 a day }\end{array}$ \\
\hline 1.2 & $\begin{array}{l}\text { By 2030, reduce at least by half the proportion of men, women and children of all ages living in poverty in all its } \\
\text { dimensions according to national definitions }\end{array}$ \\
\hline 1.3 & $\begin{array}{l}\text { Implement nationally appropriate social protection systems and measures for all, including floors, and by } 2030 \\
\text { achieve substantial coverage of the poor and the vulnerable }\end{array}$ \\
\hline 1.4 & $\begin{array}{l}\text { By 2030, ensure that all men and women, in particular the poor and the vulnerable, have equal rights to economic } \\
\text { resources, as well as access to basic services, ownership and control over land and other forms of property, } \\
\text { inheritance, natural resources, appropriate new technology and financial services, including microfinance }\end{array}$ \\
\hline 1.5 & $\begin{array}{l}\text { By 2030, build the resilience of the poor and those in vulnerable situations and reduce their exposure and } \\
\text { vulnerability to climate-related extreme events and other economic, social and environmental shocks and } \\
\text { disasters }\end{array}$ \\
\hline $1 . \mathrm{a}$ & $\begin{array}{l}\text { Ensure significant mobilization of resources from a variety of sources, including through enhanced development } \\
\text { cooperation, in order to provide adequate and predictable means for developing countries, in particular least } \\
\text { developed countries, to implement programmes and policies to end poverty in all its dimensions }\end{array}$ \\
\hline $\begin{array}{l}\text { Create sound policy frameworks at the national, regional and international levels, based on pro-poor and gender- } \\
\text { sensitive development strategies, to support accelerated investment in poverty eradication actions }\end{array}$ \\
\hline So
\end{tabular}

Source: UN General Assembly (2015, p. 14)

\section{Research Methodology}

Given that the SDGs are yet new enough that conclusions regarding their achievement are too early to be well-formed, this study examined how HCD and institutional capabilities will be shown to support SDGs 1 and 2 implementation in Nigeria. Both quantitative and qualitative research methods were used in order to address the research questions highlighted in the study. This is because a single research method is deficient in providing sufficient and exact study results. This includes engagement of the RPTBs and some selected member of staff that has direct dealing with agricultural policies and the implementation of $\mathrm{HC}$ empowerment scheme in the ministry.

\section{Understanding the SDGs 2030 Agenda: An Overview}

The SDGs are geared toward achieving the post2015 development agenda of the United Nations which aims to end poverty and improve the lives of the citizens. However, recent study on the outcome of development policies showed that the immediate past 2015 MDGs in Nigeria did not achieve the desired results as stated in the policy framework (Ezirim et al. 2016). Thus, the scourge of poverty is still been felt by the majority of the citizens (UNDP 1998; Anger 2010). World over, public policies are implemented primarily by career officials working in government ministries and/or agencies (Offu et al. 2018). Career officials are responsible for coordinating, monitoring, and enforcing implementation activities (Ezeani 2006) of various HCFSP and poverty reduction 
Paradox of Human Capital Development and SDGs Implementation in Nigeria, Table 2 Specific targets of SDG 2 - end hunger, achieve food security and improved nutrition, and promote sustainable agriculture

\begin{tabular}{|c|c|}
\hline \multicolumn{2}{|c|}{$\begin{array}{l}\text { ZERO } \\
\text { HONGER }\end{array}$} \\
\hline 2.1 & $\begin{array}{l}\text { By } 2030 \text {, end hunger and ensure access by all people, in particular the poor and people in vulnerable situations, } \\
\text { including infants, to safe, nutritious and sufficient food all year round }\end{array}$ \\
\hline 2.2 & $\begin{array}{l}\text { By } 2030 \text {, end all forms of malnutrition, including achieving, by } 2025 \text {, the internationally agreed targets on } \\
\text { stunting and wasting in children under } 5 \text { years of age, and address the nutritional needs of adolescent girls, } \\
\text { pregnant and lactating women and older persons }\end{array}$ \\
\hline 2.3 & $\begin{array}{l}\text { By } 2030 \text {, double the agricultural productivity and incomes of small-scale food producers, in particular women, } \\
\text { indigenous peoples, family farmers, pastoralists and fishers, including through secure and equal access to land, } \\
\text { other productive resources and inputs, knowledge, financial services, markets, and opportunities for value } \\
\text { addition and non-farm employment }\end{array}$ \\
\hline 2.4 & $\begin{array}{l}\text { By } 2030 \text {, ensure sustainable food production systems and implement resilient agricultural practices that increase } \\
\text { productivity and production, that help maintain ecosystems, that strengthen capacity for adaptation to climate } \\
\text { change, extreme weather, drought, flooding and other disasters and that progressively improve land and soil } \\
\text { quality }\end{array}$ \\
\hline 2.5 & $\begin{array}{l}\text { By } 2020 \text {, maintain the genetic diversity of seeds, cultivated plants and farmed and domesticated animals and their } \\
\text { related wild species, including through soundly managed and diversified seed and plant banks at the national, } \\
\text { regional and international levels, and promote access to and fair and equitable sharing of benefits arising from the } \\
\text { utilization of genetic resources and associated traditional knowledge, as internationally agreed }\end{array}$ \\
\hline 2.a & $\begin{array}{l}\text { Increase investment, including through enhanced international cooperation, in rural infrastructure, agricultural } \\
\text { research and extension services, technology development and plant and livestock gene banks in order to enhance } \\
\text { agricultural productive capacity in developing countries, in particular least developed countries }\end{array}$ \\
\hline 2.b & $\begin{array}{l}\text { Correct and prevent trade restrictions and distortions in world agricultural markets, including through the parallel } \\
\text { elimination of all forms of agricultural export subsidies and all export measures with equivalent effect, in } \\
\text { accordance with the mandate of the Doha Development Round }\end{array}$ \\
\hline 2.c & $\begin{array}{l}\text { Adopt measures to ensure the proper functioning of food commodity markets and their derivatives and facilitate } \\
\text { timely access to market information, including on food reserves, in order to help limit extreme food price } \\
\text { volatility }\end{array}$ \\
\hline
\end{tabular}

Source: UN General Assembly (2015, p. 15)

schemes in the state. The capabilities of government bureaucracy in terms of expertise, skill orientation, and experience determine to a large extent the success or failure of implementation. Policy analysis and implementation is a multidisciplinary and systematic investigation aimed at gathering and analyzing information about likely consequences of public policies both before and after they occur (Ezeani 2006) and the activities that are carried out in light of established policies in other to facilitate reading of sound policy decisions. Thus, effective performance of public services is underpinned by certain core values, which include integrity, meritocracy, discipline, professionalism, patriotism, and impartiality (Idike et al. 2019).

Thus, following expiration of the Millennium Development Goals' (MDGs) and the adoption of the 2015-2030 United Nations (UN) Sustainable Development Goals (SDGs) with 17 Goals by world leaders on September 25, 2015, it is imperative to examine the ways in which HCD can help to achieve government implemented policy programs and poverty reduction since the SDGs are 
global bold commitment of promoting inclusive and sustainable strategy on the approaches that will produce solutions to the problems of poverty, food security, inequality and injustice, and tackle climate change by 2030 (Ogu 2019).

However, the nature of PPI for development by successive governments on tackling food security and poverty alleviation in Nigeria have severally been engrossed on provision of empowerment schemes with little focus on determining the human capital capabilities of various implementing agencies/ministries and whether end users of policies (RPTBs) possess the skill to respond to the challenges they may face in trying to implement food security policies in the state. Curiously, successive governments have been churning out policies after policies without taking the challenge posed by human capital development into account, especially the target beneficiaries of reforms in the remote communities of the state. Both the bureaucrats (policy drivers) and farmers are suddenly ambushed by policies they know little about and are illequipped to support. The result is often emergency make-shift interventions which come as short-term skill training, enlightenment programs, etc., also, in the arranged process, the main producers of food (the professional farmers) are left out, as the entire process is riddled with politics while the RPTBs lack capacity and training needed to succeed in the PPI process.

This entry therefore examines agricultural (food security) policies and poverty reduction programs of the state government, with a view to underscoring the human capital challenges which had led to evident policies failures. Governments armed by what they perceive to be the problem of Nigeria and the solutions thereof have implemented various kinds of policies; some are outright new policies whereas others are modified versions of existing ones. All of these failed to launch Nigeria on the path of growth and development. This entry believing that agriculture holds the miraculous key that will unlock Nigeria's growth potentials looks at the other end of the human capital challenges and their implications for policies success or failures for the attainment of rapid sustainable ecological, economic, and sociocultural development in the economy. It is a modest contribution to the debate on policies for development, food security, and poverty alleviation.

\section{SDGs Analytical Framework and the Need for SHCI Policy Reform}

From the targets of SDGs 1 and 2 as contained in Tables 1 and 2 below, it is imperative to state that SHCI policy reform through constant training and retraining of the policy drivers (HCs) and the RPTBs will help to drive the success and sustainability of the empowerment schemes in Ebonyi state. Since empowerment of citizens closes inequality gap through the outcome people/citizens' involvement in the project community and decision-making process.

The people's active participation can further lead to capacity building and policy sustainability. This agrees with scholarly position that skewed allocation of HCI benefits becomes an avenue to compensate and enrich political loyalists and acolytes to the disadvantage of intended target social strata (Ukeje et al. 2020a, p. 4).

In Ebonyi state, this target social strata lacks the $\mathrm{HC}$ capacity and capability to combat and manage the world global economic crisis, destruction of natural ecosystems leading to considerable losses in biodiversity, issues of global climate changes, extensive land degradation and deforestation, testing of soil $\mathrm{pH}$, change in technology, pest and disease control, use of improved seedlings, increase in soil, air, and water pollution, flood, COVID 19, poverty and agricultural related challenges due to lack of training and capacity building, etc. The above stated issues have posed a serious challenge/threat to human survival and existence in this present era of SDGs across the globe. Even the presence of EBSMoANRs have not developed the capacity and capability to manage and/or deliver HCI policy framework that will help in addressing the issues in a sustained manner.

Table 3 shows that $88 \%$ of the participants strongly agreed that in spite of the role of the ministry and their involvement in implementing 
Paradox of Human Capital Development and SDGs Implementation in Nigeria, Table 3 Respondents' views on the nature of HCFSP and poverty reduction in Ebonyi state

\begin{tabular}{|c|c|c|c|}
\hline & Opinion & $\begin{array}{l}\text { Strongly } \\
\text { agreed }(\%)\end{array}$ & $\begin{array}{l}\text { Strongly } \\
\text { disagreed } \\
(\%)\end{array}$ \\
\hline A & $\begin{array}{l}\text { Determining the impact of } \mathrm{HC} \text { food security program on poverty reduction } \\
\text { in Ebonyi State }\end{array}$ & & \\
\hline 1 & $\begin{array}{l}\text { Has your ministry been involved in implementing food security and poverty } \\
\text { reduction program in the state? }\end{array}$ & $220(88 \%)$ & $30(12 \%)$ \\
\hline 2 & $\begin{array}{l}\text { Has your ministry had specific strategy/method for identifying those who } \\
\text { benefit from the HC intervention scheme? }\end{array}$ & $180(72 \%)$ & $70(28 \%)$ \\
\hline 3 & $\begin{array}{l}\text { Has the previous HC intervention strategy been effective in reducing poverty } \\
\text { reduction? }\end{array}$ & $117(47 \%)$ & $133(53 \%)$ \\
\hline 4 & Has food security had significant impact on poverty reduction in the state? & $109(44 \%)$ & $141(56 \%)$ \\
\hline 5 & Has the agro-empowerment scheme reduced poverty at the local level? & $78(31 \%)$ & $172(69 \%)$ \\
\hline 6 & $\begin{array}{l}\text { Is there a high level of awareness by the real farmers on government's food } \\
\text { security program? }\end{array}$ & $69(28 \%)$ & $181(72 \%)$ \\
\hline B & $\begin{array}{l}\text { The level of poverty rate in Ebonyi State despite the successive policy on } \\
\text { poverty reduction by the government }\end{array}$ & & \\
\hline 7 & $\begin{array}{l}\text { Do you think poverty has persisted in the state in spite of government } \\
\text { intervention programs? }\end{array}$ & $157(63 \%)$ & $93(37 \%)$ \\
\hline 8 & $\begin{array}{l}\text { Do you think the use of farmers' cooperative society is effective in achieving } \\
\text { food security? }\end{array}$ & $139(56 \%)$ & $111(44 \%)$ \\
\hline 9 & Has the agro-empowerment scheme reduced poverty in the state? & $98(39 \%)$ & $152(61 \%)$ \\
\hline 10 & $\begin{array}{l}\text { Are there challenges facing the implementation of the agro-empowerment } \\
\text { program? }\end{array}$ & $132(53 \%)$ & $118(47 \%)$ \\
\hline 11 & $\begin{array}{l}\text { Do the beneficiaries of the empowerment scheme lack knowledge/skill needed } \\
\text { for poverty reduction? }\end{array}$ & $139(56 \%)$ & $111(44 \%)$ \\
\hline 12 & Have many farmers benefitted from the agro-empowerment scheme? & $132(52.8 \%)$ & $118(47.2 \%)$ \\
\hline $\mathbf{C}$ & Challenges facing food security programs implementation in the state & & \\
\hline 13 & Are there adequate training facilities/programs for staff in your ministry? & $142(56.8 \%)$ & $108(43.2 \%)$ \\
\hline 14 & Is there regular training of staff based on food security challenges in the state? & $119(47.6 \%)$ & $131(52.4 \%)$ \\
\hline 15 & $\begin{array}{l}\text { Have you participated from some capacity building programs like seminars, } \\
\text { workshops, conferences, etc., in your ministry? }\end{array}$ & $137(55 \%)$ & $113(45 \%)$ \\
\hline 16 & $\begin{array}{l}\text { Are there programs designed by your ministry to manage issues of climate } \\
\text { change, soil } \mathrm{pH} \text {, pest and disease control, use of improved seedlings, etc. }\end{array}$ & $77(31 \%)$ & $173(69 \%)$ \\
\hline 17 & $\begin{array}{l}\text { Were the current beneficiaries of the agricultural intervention scheme trained on } \\
\text { how to manage climate change challenges? }\end{array}$ & $98(39 \%)$ & $152(61 \%)$ \\
\hline 18 & Are the selection processes of the food security policy program transparent? & $59(24 \%)$ & $191(76 \%)$ \\
\hline
\end{tabular}

Source: Ukeje's Field Survey (2019) cited in Ukeje (2020)

food security and poverty reduction program that poverty and hunger has persisted in the state in spite of laudable government intervention schemes/programs. Seventy-two percent of the respondents also agreed that the ministry had specific strategy/method for identifying those who benefit from the intervention scheme but that the selection processes is challenged by virtues of transparency, meritocracy, and professionalism due to the ever presence of politics and state- elite capture. This indicates that, in general, most of the professionals in the ministry had good knowledge and skill toward the success and/or failure of any policy but disagreed on the impact (outcome) of services provided by the extension agents. This is because most of the local stakeholders in the various 13 local government areas (LGAs) were not involved in the entire governance processes for sustainable food security projects. This has challenged the entire process of 
HCD - inclusion, eligibility, screening, identification, acquisition, training, and utilization because most of the RPTBs were not only selected on grounds of merit but were not trained on how to manage climate change challenges, soil $\mathrm{pH}$, pest and disease control, use of improved seedlings, etc., before receiving the empowerment scheme from the state government, thereby affecting sustainable poverty reduction schemes/strategies at the local level.

\section{Discussion and Policy Implications}

In this era of SDGs, it is pertinent to state that empowerment of the right HCs at both the institutional and community levels will serve as catalyst for socioeconomic development and sustainability of any developmental project in Nigeria. They are a veritable vehicle for the achievement of national policy objectives in terms of PPI. However, based on the findings of this entry, the major challenge facing the attainment of SDGs 1 and 2 in Abakaliki metropolis is lack of HCD of the implementing ministry/agency to enable them to acquire more skills to drive the policy and the noninvolvement of the RPTBs in the various stages of the policy cycle - project identification, planning, implementation, monitoring, and evaluation. This agrees with the assertion that "interventions targeted at the poor were characterized by exclusion and inclusion mechanisms in which the privileged political agency profiteers hijacked the intervention opportunities, thereby unjustly displacing RPTBs" (Ukeje et al. 2020a, p. 4).

\section{Conclusion}

For organizational effectiveness and sustainability, HCD policies must be sound, efficient, impartial, and free from politics in order to be able to implement government policies (see Table 3). This entry examined the paradox of HCD and SDGs focusing on goals (1 and 2) policy implementation framework for the attainment of poverty reduction and food security program in
Ebonyi state, Nigeria. The motivation behind this research is based on the fact that several development efforts taken by successive governments in tackling food security and poverty reduction in the state since creation in 1996 to date have often ignored the HCD need of the "policydrivers" and the RPTBs for PPI success and sustainability in the policy agenda. The study revealed the need for EBSMoANRs to review its civil service operations and establish clear-cut HCD strategies that are in sync with the framework of SDGs 1 and 2 policy targets (see Tables 1 and 2) to be able to implement government policies. This will help to eliminate inefficiency and corruption in the development of right HCs based on need assessment indicators and sustainability (see Fig. 1).

For the attainment of sustainable HCIPs in Ebonyi state, the practice of using CSOs in disbursing the HCI schemes should be discontinued. Importantly, the professional personnel's (agricultural experts) in the federal and state tertiary institutions like the faculties of agriculture at both the Alex Ekwueme Federal University, Ndufu-Alike and the Ebonyi State University, Abakaliki should be involved in the conception (policy design) of the various HCIPs in the ministry. This will lead to the development of institutional reforms and capacity building for sustainability within the ministry and beyond. Moreover, the use of LCBPIMs is preferred as a better and result-oriented participatory governance/approach that encourages strong synergy between the citizens and the implementing ministry/agency (Ukeje 2020). The study argues that challenges bordering on faulty implementation of HCD and poverty reduction strategies has negatively affected policy sustainability and so recommend alternative models for enhancing HCI outcomes and performance. Thus, the need for new HCIRs in the ministry for the attainment of SHCI policy reforms and sustainability remains a sine qua non for the attainment of sound governance in the state. 


\section{Cross-References}

Building Human Capital for Sustainable
Development
- Governance and Human Development
- Human Capital Intervention and Poverty
Reduction
- Human Capital Intervention Policy
- Participatory Development and Empowerment
- Policy-Making for Sustainable Empowerment
- Politics of Public Policy
- Sound Governance
- Sustainable Human Capital Development

\section{References}

Agyepong IA, Adjei S (2007) Public social policy development and implementation: a case study of the Ghana National Health Insurance Scheme. Health Policy Plan 23:150-160

Anger B (2010) Poverty eradication, millennium development goals and sustainable development in Nigeria. J Sustain Dev 3(4):138-144

Anyanwu JC (2011) Towards reducing poverty in Nigeria: the case of Igboland. J Econ Int Financ 3(9):513-528

Atkinson CL (2017) Rural development policy. In: Farazmand A (ed) Global encyclopedia of public administration, public policy, and governance. Springer, Cham. https://doi.org/10.1007/978-3-31931816-5_1014-1

Ayisi EK, Yeboah-Assiamah E, Bawole JN (2018) Politics of public policy implementation: case of Ghana National Health Insurance Scheme. In: Farazmand A (ed) Global encyclopedia of public administration, public policy, and governance. Springer, Cham. https:// doi.org/10.1007/978-3-319-31816-5_3395-1

Bene C, Oosterveer P, Lamotte L, Brouwer ID, Haan S, Prager SD, Talsma EF, Khoury CK (2019) When food systems meet sustainability - current narratives and implications for actions. World Dev 113:116-130

Dialoke I, Ukah FO, Maduagwuna IV (2017) Policy formulation and implementation in Nigeria: the bane of underdevelopment. Int J Capacit Build Educ Manag 3(2):22-27

Dzanku FM (2019) Food security in rural sub-Saharan Africa: Exploring the nexus between gender, geography and off-farm employment. World Develop 113:2643

Ezeani EO (2006) Fundamentals of public administration. Snaap Press, Enugu

Ezirim EG, Nnamani KE, Onah VC, Agbo HN, Ike CC (2016) Political science as prospect for achieving sustainable development goals in Nigeria. Mediterr J Soc Sci 7(5):319-334
Farazmand A (2004) Sound governance: policy and administrative innovations. Praeger, Westport

Farazmand A (2012) Sound governance: engaging citizens through collaborative organizations. Public Organ Rev $12: 223-241$

Farazmand A (2017) Governance reforms: the good, the bad, and the ugly; and the sound: examining the past and exploring the future of public organizations. Public Organ Rev 17:595-617

Fatile JO, Ajulor OV (2018) Policy formulation and implementation dichotomy and rural poverty reduction in Nigeria. J Public Policy 5(2):1-12

Fischer-Smith R (2018) Adjusting policy implementation frameworks for non-pluralist conditions: a case study of Ukraine's single tax for small business. Admin Dev 38:26-38. https://doi.org/10.1002/pad.1818

Grace FC, Meurk CS, Head BW, Hall WD, Harris MG, Whiteford HA (2017) An analysis of policy success and failure in formal evaluations of Australia's National Mental Health Strategy (1992-2012). BMC Health Serv Res 17:374. https://doi.org/10.1186/s12913-0172309-x

Howlett M, Ramesh M (2003) Studying Public Policy: policy cycles and policy subsystems. Oxford University Press, Toronto

Idike A, Ukeje IO, Iwuala HO, Onele JC, Ekwunife RA, Nwachukwu K, Ogbulu U (2019) The practice of inclusive representation in Nigeria bureaucracy: the Federal Character Principle experience. Cogent Soc Sci. https:// doi.org/10.1080/23311886.2019.1601545

Ighodalo A (2018) Public administration and sustainable national development in Nigeria's fourth republic. Adv Soc Sci Res J 5(3):466-478

Jaiyesimi R (2016) The challenge of implementing the sustainable development goals in Africa: the way forward. Afr J Reprod Health 20(3):13-18

Jooji IT, Oguchi CB (2017) Qualitative manpower development through effective public policies: the pathway to sustainable development in Nigeria. Int J Innov Res Soc Sci Strateg Manag Tech 4(2):1-13

Kauzya JM (2015) From implementation of MDGs to 2030 sustainable development agenda: what will it take from government and public administration to achieve sustainable development goals (SDGs). Paper presented during the 20th CLAD Congress, Lima, Nov 2015

McConnell A (2015) What is policy failure? A primer to help navigate the maze

Metu AG, Okeyika KO, Maduka OD (2016) Achieving sustainable food security in Nigeria: challenges and way forward. In: Third international conference on African development issues. Covenant University Press, Ota, pp 182-187

Momen MN, Begum MM (2020) Sustainability and governance. In: Farazmand A (ed) Global encyclopedia of public administration, public policy, and governance. Springer, Cham. https://meteor.springer.com/project/ dashboard.jsf?id=273

Ndukwe C, Ukeje IO, Onele JC (2015) Leadership styles and the politics of institutional management of state- 
owned universities in Nigeria: empirical evidence from EBSU, South-Eastern geo-political zone, Nigeria. Int J Humanit Soc Sci 4(6):91-102. http://www.iaset.us/view archives.php?year $=2015 \&$ id $=72 \&$ jtype $=2 \&$ page $=5$

Ndukwe C, Elom C, Ukeje IO, Anigbata DO (2016) Re-positioning human resource practitioners for effective change management in times of severe austerity: a policy framework for service delivery in Nigeria public sector. J Resour Dev Manag 22:40-49. http://iiste.org/Journals/index.php/JRDM/article/view/ 31748

O'Toole LJ Jr (2004) The theory-practice issue in policy implementation research. Public Adm 82(2):309-329

Offu PO, Ukeje IO, Offu OF (2018) Service: the matrix of good governance in Nigeria-Africa. In: Farazmand A (ed) Global encyclopedia of public administration, public policy, and governance. Springer, Cham. https:// doi.org/10.1007/978-3-319-31816-5_3499-1

Ogu EC (2019) Sustainable development and the social consequence of bureaucracy. In: Farazmand A (ed) Global encyclopedia of public administration, public policy, and governance. Springer, Cham. https:// doi.org/10.1007/978-3-319-31816-5_3714-1

Ojo EO, Adebayo PF (2012) Food security in Nigeria: An overview. Eur J Sustain Dev 1(2):199-220

Okechukwu GP, Ukeje IO, Ekwunife RA (2016) The melting point between SERVICOM and service failure: a labyrinth for efficient service delivery in Nigeria. IOSR J Humanit Soc Sci 21(5):01-10. http://www. iosrjournals.org/iosr-jhss/pages/21(5)Version-2.html

Okpata FO, Ukeje IO (2011) Bureaucratic communication in organizational management: the challenge of new employees in public service organization. Niger J Bus 5(1):234-240

Olavarria-Gambi M (2018) Policy failure. In: Farazmand A (ed) Global encyclopedia of public administration, public policy, and governance. Springer, Cham. https:// doi.org/10.1007/978-3-319-31816-5_3182-2

Onah FO (2010) Managing public programmes and projects, 2nd edn. Great AP Express Publishers, Nsukka

Osawe CO (2015) Nigerian public service performance in a dysfunctional ecology: issues, challenges and the way forward. Rev Public Adm Manag 3(7):45-57

Ozoya MI (2016) Empowerment of rural women farmers and food production in Esan West Local Government Area of Edo State, Nigeria. Being an unpublished PhD thesis, Covenant University Center for Learning Resources

Parsons W (1995) Public Policy: an introduction to the theory and practise of policy analysis. Cheltenham, Edward Elgar
Ricciardelli A (2018) Governance, local communities, and citizens participation. In: Farazmand A (ed) Global encyclopedia of public administration, public policy, and governance. Springer, Cham. https://doi.org/ 10.1007/978-3-319-31816-5_3221-1

Thornton P, Dinesh D, Cramer L, Loboguerrero AM, Campbell B (2018) Agriculture in a changing climate: keeping our cool in the face of the hothouse. Outlook Agric 47(4):283-229

Ukeje IO (2020) Human capital development and implementation of food security and poverty reduction policy in Nigeria: a study of Ebonyi State Ministry of Agriculture and Natural Resources (1996-2018). Unpublished $\mathrm{PhD}$ Thesis, Department of Public Administration, Nnamdi Azikiwe University, Awka, Nigeria

Ukeje IO, Ogbulu U, Onyema UE, Obi V, Obasi VU (2019) Bureaucratization and service delivery in Nigeria. In: Farazmand A (ed) Global encyclopedia of public administration, public policy, and governance. Springer, Cham

Ukeje IO, Ogbulu U, Amaefula VC (2020a) Human capital intervention and poverty reduction. In: Farazmand A (ed) Global encyclopedia of public administration, public policy, and governance. Springer, Cham. https:// doi.org/10.1007/978-3-319-31816-5_3876-1

Ukeje IO, Ogbulu U, Idike AN, Ndukwe C, Iwuala H, Clementina K (2020b) Policy-making for sustainable empowerment and poverty reduction scheme in Nigeria. In: Farazmand A (ed) Global encyclopedia of public administration, public policy, and governance. Springer, Cham. https://doi.org/10.1007/978-3-31931816-5_3922-1

Ukeje IO, Ndukwe C, Chukwuemeka E, Ogbulu U, Onele JP (2020c) Public service recruitment practices and implications for sustainable development in Ebonyi State, Nigeria. Int J Public Adm. https://doi.org/ 10.1080/01900692.2019.1636394

UNDP Report (1998) Poverty Reduction Strategies in Nigeria in Onah, F. O. (2010) Managing Public Programmes and Projects. Second Edition, Nsukka, Nigeria. Great AP Publishers LTD.

United Nations General Assembly (2015). Resolution adopted by the general assembly on 25 September 2015, ref. A/RES/70/1. Annual report, New York

Zhang Y (2017) Theory of policy learning, China. In: Farazmand A (ed) Global encyclopedia of public administration, public policy, and governance. Springer, Cham. https://doi.org/10.1007/978-3-31931816-5 3354-1 